\title{
Proceeding
}

Supplementary Issue: Winter Conferences of Sports Science. Costa Blanca Sports Science Events, 22-23 March 2021. Alicante, Spain.

\section{Incidence and prevalence of injuries in futsal: A systematic review of the literature}

\author{
JAVIER GENE-MORALES ${ }^{1,2}$, ANGEL SAEZ-BERLANGA1, MANUEL BERMUDEZ1', JORGE FLÁNDEZ³, \\ NICOLE FRITZ4 ${ }^{4}$ JUAN C. COLADO1,5 \\ ${ }^{1}$ Research Unit in Sport and Health, University of Valencia, Valencia, Spain \\ ${ }^{2}$ Research Institute on Traffic and Road Safety (INTRAS), University of Valencia, Valencia, Spain \\ 3 Institute of Education Sciences, Austral University of Chile, Ciudad de Valdivia, Chile \\ ${ }^{4}$ Health Department, University of Los Lagos, Puerto Montt, Chile \\ ${ }^{5}$ Department of Physical Education and Sports, University of Valencia, Valencia, Spain
}

\begin{abstract}
Futsal athletes are exposed to a high number of injures. Purpose: This study aimed to gather data on the injures produced in futsal, attending to the prevalence, part of the body injured, type of injury and mechanism, and severity. Also, to evaluate the influence that sociodemographic factors and the position on the pitch may have on the injuries. Finally, we pursued to summarize the prevention strategies proposed by the expert literature. Design: Different search strategies were entered in PubMed, Scopus, Web of Science, and Sport Discuss databases. Results: 36 articles were selected to be reviewed. Futsal is situated among the sports with the highest injury incidence, being the main body part injured the lower limb, specifically the knees and ankles. Regarding the type of injury and the mechanism causing the injury, bone injuries are usually related to contact with rivals and muscle, tendon, and ligament injuries related to non-contact mechanisms. In this concern, non-contact injuries are frequently more severe than impact injuries. There is not a clear consensus on if more injuries occur in training or games, and on the severity of the major part of the injuries that occur in futsal. Concerning sex, male players seem to present a higher prevalence of ankle injuries while woman players present more incidence of knee sprains. The age was reported to be correlated with the incidence of injuries during futsal practice. No influence of the position on the field of play on the prevalence of injuries was observed in the literature. Some recommendations are gathered concerning the prevention of injuries. These recommendations are focused on player equipment, playing facilities, rules, physical assessment, and appropriate strength and conditioning preparation. Conclusion: The results presented in this study may help coaches and practitioners to understand crucial factors on the common injuries that occur in futsal. This may allow them to prevent potential injuries and maintain the athlete's performance.
\end{abstract}

Keywords: Indoor soccer; Sprains; Ankle; Knee.

\section{Cite this article as:}

Gene-Morales, J., Saez-Berlanga, A., Bermudez, M., Flández, J., Fritz, N., \& Colado, J.C. (2021). Incidence and prevalence of injuries in futsal: A systematic review of the literature. Journal of Human Sport and Exercise, 16(3proc), S1467-S1480. https://doi.org/10.14198/ihse.2021.16.Proc3.63

Corresponding author. Department of Physical Education and Sports, University of Valencia, C/ Gascó Oliag 3, 46010 Valencia, Spain. https://orcid.org/0000-0002-3255-3940

E-mail: juan.colado@uv.es

Abstract submitted to: Winter Conferences of Sports Science. Costa Blanca Sports Science Events, 22-23 March 2021. Alicante, Spain.

JOURNAL OF HUMAN SPORT \& EXERCISE ISSN 1988-5202.

(c) Faculty of Education. University of Alicante.

doi:10.14198/jhse.2021.16.Proc3.63 


\section{INTRODUCTION}

Futsal is an indoor team sport played between two teams of five players, including the goalkeeper, on a parquet or synthetic pitch of 40x20 meters. Matches have a total duration of 40 minutes divided into two times of 20 minutes each, the time stops when the ball is not in play (International Federation of Association Football [FIFA], 2013). This sport is characterised by intermittent high-intensity actions with varying resting opportunities, from full to partial recoveries (Ferreira et al., 2010). Short sprints, changes of rhythm and direction, ball control, and interaction with rivals are the main actions that take place in futsal (Zagalaz, 2011; Zagalaz et al., 2012). All these specific features altogether with overloading periods due to training and competitions, make futsal a sport with a high prevalence of injuries (Cain et al., 2007; Ribeiro et al., 2003).

Injuries are defined as musculoskeletal damage that withdraws athletes from competition. It is crucial to understand the origin and reach of injuries to be able to design preventive interventions (Ladeira, 1999; Morato et al., 2013). Prevention programs are multidisciplinary interventions that are relevant to maintain athletes at their maximum level of performance and avoid unnecessary time and money expenditures (Bahr, 2007; Baroni \& Leal, 2010; Engström \& Renström, 1998; Panchuk \& Glab, 2015). Bearing in mind that epidemiological studies allow to follow up the incidence, prevalence, characteristics, frequency of injuries both in the short and long term (Junge et al., 2004), the necessity arises of gathering information on the incidence, prevalence, and prevention of injuries in futsal.

Due to all these aforementioned factors, this study aimed to systematically review the literature to gather data on the most common injures produced in futsal, attending specifically to the prevalence, part of the body and region injured, type of injury and mechanism, and severity. Also, we intended to evaluate the influence that sociodemographic and other factors related to the sport, such as the position on the pitch, may have on the injuries. Finally, we pursued to summarize the prevention strategies proposed by the expert literature.

\section{METHODS}

For this systematic review, the protocols of the PRISMA declaration (Hutton et al., 2015; Urrútia \& Bonfill, 2010) and the items proposed by Aranda (2006) were followed.

\section{Search strategy}

After designing the study, the first step was to design the keyword for the search. Four databases (Web of Science, PubMed, Scopus, and SportDiscus) were consulted to collect information on the incidence, prevalence and prevention of injuries in futsal. Original articles and systematic reviews from 1992 to 2020 were retrieved to be further analysed. No language restrictions were applied. The following terms were used: ("indoor soccer" OR "indoor football" OR "futsal" OR "5-a-side" OR "five-a-side") AND ("injury" OR "injuries" OR "lesion" OR "lesions" OR "wound" OR "wounds" OR "damage" OR "hurt" OR "harm" OR "epidemiology" OR "epidemiological" OR "epidemiologic" OR "prevention" OR "prevent" OR "forestalling" OR "precaution" OR "protective").

\section{Eligibility criteria and article selection}

To be included the studies had to 1) study the incidence and/or prevalence of injuries in futsal, 2) present prevention strategies. Studies analysing injuries in soccer were excluded. The search strategies were entered in the aforementioned databases and a screening of titles and abstracts was carried out to identify potentially relevant studies. The selected studies after the first screening were reviewed to ensure their eligibility for further analyses. 


\section{Data processing}

After carefully reading the selected articles, we selected 1) the injury rate, 2) type, 3) body part injured, 4) body segment injured, 5) moment of occurrence (training or competition), 6) severity, 7) injury mechanism, 8) relationship position on the field-injury, 9) relationship sex-injury, and 10) relationship age-injury, as the main variables to analyse concerning the incidence of injuries. The prevention strategies included were related to 1) the material, 2) equipment, 3) facilities and infrastructures, 4) regulation, 5) strength and conditioning, 6) physical assessment, 7) training programs, 8) hydration, 9) nutrition, and 10) recovery.

\section{RESULTS}

After carrying out all the aforementioned steps, 67 articles were selected to be analysed. Out of the 67 studies, 37 (35 original studies, 2 reviews) studied the incidence and prevalence of injuries in futsal and 31 original articles studied prevention strategies. The main characteristics and contents of the articles can be found in Table 1 (prevalence and incidence of injuries) and Table 2 (injury-prevention strategies).

It is worth highlighting that the most studied variable related to futsal injuries is the body segment injured (15 studies), followed by the injury rate and mechanism (13 publications each) and the body part and type of injury (12 publications each). The severity of the injury was examined in 9 studies and 8 articles compared the injuries that occurred in training with those happening in competition. The variables gender and position on the field and their influence on the injuries were evaluated by 6 publications. Finally, 4 articles analysed the effect of gender on injury prevalence.

Table 1. Studies $(n=36)$ analysing the incidence of injuries in futsal.

\begin{tabular}{|c|c|c|c|c|c|c|}
\hline Publication & Design & Sample & Methodology & $\begin{array}{l}\text { What authors } \\
\text { understand by } \\
\text { injury }\end{array}$ & $\begin{array}{l}\text { Study } \\
\text { variables }\end{array}$ & Results \\
\hline $\begin{array}{l}\text { Willick et al. } \\
(2013)\end{array}$ & Prospective & $\begin{array}{l}3,565 \\
\text { athletes } \\
(1,218 \text { female } \\
\text { and } 2,347 \\
\text { male) } \\
\text { Age: } 30 \\
\text { years (mean) }\end{array}$ & $\begin{array}{l}\text { Duration: } 14 \text { days } \\
\text { Way of } \\
\text { measurement: } \\
\text { National Paralympic } \\
\text { Committee medical } \\
\text { staff daily } \\
\text { underwent a } \\
\text { questionnaire. } \\
\text { Training/competition } \\
\text { : both }\end{array}$ & $\begin{array}{l}\text { A musculoskeletal } \\
\text { complaint that } \\
\text { requires medical } \\
\text { attention. No matter } \\
\text { if the athlete loses } \\
\text { training or } \\
\text { competition. }\end{array}$ & $\begin{array}{l}\text { Rate } \\
\text { Mechanism }\end{array}$ & $\begin{array}{l}\mathrm{IR} 22.4 \\
\text { injuries } / 1,000 \\
\text { practice days } \\
\uparrow \% \text { acute } \\
\text { injuries }\end{array}$ \\
\hline $\begin{array}{l}\text { Varkiani et } \\
\text { al. (2013) }\end{array}$ & Retrospective & $\begin{array}{l}1,045 \\
\text { athletes } \\
(914 \text { male } \\
\text { and } 104 \\
\text { female) } \\
\text { Age: } \\
31.82 \pm 19.31 \\
\text { years }\end{array}$ & $\begin{array}{l}\text { Duration: } 1 \text { year } \\
\text { Way of } \\
\text { measurement: } \\
\text { direct data retrieval } \\
\text { from the Medical } \\
\text { System of Injury } \\
\text { Screening from the } \\
\text { Iran Futsal } \\
\text { Federation } \\
\text { Training/competition } \\
\text { : both }\end{array}$ & $\begin{array}{l}\text { An occurrence that } \\
\text { takes place during a } \\
\text { competition or } \\
\text { training, requires } \\
\text { medical attention, } \\
\text { and withdraw the } \\
\text { athlete from } \\
\text { competing or } \\
\text { training at least one } \\
\text { day after the } \\
\text { occurrence. }\end{array}$ & $\begin{array}{l}\text { Rate } \\
\text { Body } \\
\text { region } \\
\text { Body part } \\
\text { Age } \\
\text { Gender }\end{array}$ & $\begin{array}{l}\text { IR } 8.1 \\
\text { injuries/1,000 } \\
\text { athletes } \\
\uparrow \% \text { lower-limb } \\
\text { injuries } \\
\uparrow \% \text { knee } \\
\text { injuries } \\
\uparrow \text { number of } \\
\text { injuries } \\
\text { between } 15 \\
\text { and } 24 \text { years } \\
\text { old } \\
\uparrow \text { number of } \\
\text { injuries in male }\end{array}$ \\
\hline
\end{tabular}




\begin{tabular}{|c|c|c|c|c|c|c|}
\hline $\begin{array}{l}\text { Quemelo et } \\
\text { al. (2012) }\end{array}$ & Retrospective & $\begin{array}{l}6,923 \\
\text { athletes } \\
\text { Age: } \\
23.0 \pm 5.9 \\
\text { years }\end{array}$ & $\begin{array}{l}\text { Duration: } 10 \text { days } \\
\text { Way of } \\
\text { measurement: } \\
\text { questionnaire } \\
\text { Training/competition } \\
\text { : both }\end{array}$ & $\begin{array}{l}\text { An occurrence that } \\
\text { takes place during a } \\
\text { game or training } \\
\text { and that forces the } \\
\text { athlete to stop } \\
\text { competing or } \\
\text { training during a } \\
\text { period to underwent } \\
\text { medical treatment. }\end{array}$ & $\begin{array}{l}\text { Body } \\
\text { region } \\
\text { Body part }\end{array}$ & $\begin{array}{l}\uparrow \% \text { lower-limb } \\
\text { injuries } \\
\uparrow \% \text { knee } \\
\text { injuries }\end{array}$ \\
\hline $\begin{array}{l}\text { Morato et } \\
\text { al. (2013) }\end{array}$ & Prospective & 13 athletes & $\begin{array}{l}\text { Duration: } 4 \\
\text { tournaments Way of } \\
\text { measurement: } \\
\text { Brazilian Paralympic } \\
\text { Committee and } \\
\text { Brazilian } \\
\text { Confederation of } \\
\text { Blind Athletes Injury } \\
\text { Report Form } \\
\text { Training/Competitio } \\
\text { n: competition }\end{array}$ & $\begin{array}{l}\text { An occurrence that } \\
\text { causes an athlete to } \\
\text { retire from } \\
\text { competition during } \\
\text { one or more events. }\end{array}$ & $\begin{array}{l}\text { Rate } \\
\text { Mechanism } \\
\text { Body } \\
\text { region } \\
\text { Type }\end{array}$ & $\begin{array}{l}\text { IR } 0.12 \\
\text { injuries/game } \\
\uparrow \% \text { contact } \\
\text { injuries } \\
\uparrow \% \text { lower-limb } \\
\text { injuries } \\
\uparrow \% \\
\text { contusions }\end{array}$ \\
\hline
\end{tabular}

Table 2. Results related to the futsal injury production variables.

\begin{tabular}{|c|c|c|c|c|c|c|}
\hline Publication & $\begin{array}{l}\text { Body region } \\
\text { injured }\end{array}$ & $\begin{array}{l}\text { Body part } \\
\text { injured }\end{array}$ & $\begin{array}{l}\text { Production } \\
\text { mechanism }\end{array}$ & Injury type & $\begin{array}{l}\text { Injury } \\
\text { severity }\end{array}$ & $\begin{array}{l}\text { Occurred in } \\
\text { training or } \\
\text { competition }\end{array}$ \\
\hline $\begin{array}{l}\text { Quemelo et } \\
\text { al. (2012) }\end{array}$ & $\begin{array}{l}\text { Lower limb } \\
36.9 \% \\
\text { Trunk } 36.8 \% \\
\text { Upper limb } \\
18.2 \%\end{array}$ & $\begin{array}{l}\text { Knee } 23.1 \% \\
\text { Ankle } 18.1 \% \\
\text { Thigh } 17 \% \\
\text { Leg } 10.4 \%\end{array}$ & --- & --- & --- & --- \\
\hline $\begin{array}{l}\text { Varkiani et } \\
\text { al. (2013) }\end{array}$ & $\begin{array}{l}\text { Lower limb } \\
62.9 \% \\
\text { Upper limb } \\
20.3 \% \\
\text { Head and neck } \\
3.8 \%\end{array}$ & $\begin{array}{l}\text { Knee } 37.3 \% \\
\text { Ankle } 13.5 \%\end{array}$ & --- & --- & --- & --- \\
\hline $\begin{array}{l}\text { Junge \& } \\
\text { Dvorak } \\
(2010)\end{array}$ & $\begin{array}{l}\text { Lower limb } \\
69.7 \% \\
\text { Head and neck } \\
12.7 \% \\
\text { Upper limb } \\
10.3 \% \\
\text { Trunk } 7.3 \%\end{array}$ & $\begin{array}{l}\text { Knee } 15.8 \% \\
\text { Thigh } 12.9 \% \\
\text { Ankle } 12.1 \%\end{array}$ & $\begin{array}{l}\text { Contact } \\
\text { injuries 64\% } \\
\text { Non-contact } \\
36 \%\end{array}$ & $\begin{array}{l}\text { Contusion } 44.2 \% \\
\text { Sprain } 19.4 \% \\
\text { Muscle tear } 17.6 \% \\
\text { Other } 18.8 \%\end{array}$ & $\begin{array}{l}\text { (0 d.) } 43 \% \\
(1-3 \text { d.) } 26 \% \\
(4-7 \text { d.) } 4.2 \% \\
(8-28 \text { d.) } 7.9 \% \\
(>28 \text { d.) } 1.2 \% \\
\text { Non reported } \\
17.7 \%\end{array}$ & --- \\
\hline $\begin{array}{l}\text { García- } \\
\text { Tamez et al. } \\
(2011)\end{array}$ & $\begin{array}{l}\text { Lower limb } 76 \% \\
\text { Upper limb } \\
14.5 \% \\
\text { Trunk and head } \\
9.5 \%\end{array}$ & --- & $\begin{array}{l}\text { Contact } \\
\text { injuries 32\% } \\
\text { Non-contact } \\
68 \%\end{array}$ & $\begin{array}{l}\text { Sprain } 25 \% \\
\text { Contusion } 23 \% \\
\text { Muscle injury 18\% } \\
\text { Other } 34 \%\end{array}$ & $\begin{array}{l}\text { Minor } 92 \% \\
\text { Moderate } \\
6.5 \% \\
\text { Severe } 1.5 \%\end{array}$ & $\begin{array}{l}\text { Training } 72.5 \% \\
\text { Competition } \\
27.5 \%\end{array}$ \\
\hline $\begin{array}{l}\text { Ribeiro et } \\
\text { al. (2003) }\end{array}$ & $\begin{array}{l}\text { Lower limb } 79 \% \\
\text { Upper limb } 14 \% \\
\text { Head and hip } \\
7 \%\end{array}$ & $\begin{array}{l}\text { Ankle } 46 \% \\
\text { Knee } 19 \% \\
\text { Thigh } 12 \%\end{array}$ & --- & $\begin{array}{l}\text { Fracture/dislocation } \\
31 \% \\
\text { Muscle tear } 25 \% \\
\text { Tendinitis } 17 \% \\
\text { Sprain } 13 \% \\
\text { Contusion } 6 \% \\
\text { Other } 8 \%\end{array}$ & --- & --- \\
\hline
\end{tabular}




\begin{tabular}{|c|c|c|c|c|c|c|}
\hline $\begin{array}{l}\text { Morato et al. } \\
(2013)\end{array}$ & $\begin{array}{l}\text { Lower limb 80\% } \\
\text { Head } 8.6 \% \\
\text { Trunk } 5.7 \% \\
\text { Upper limb 5.7\% }\end{array}$ & $\begin{array}{l}\text { Knee } 28.6 \% \\
\text { Pie } 11.4 \% \\
\text { Thigh } 11.4 \%\end{array}$ & $\begin{array}{l}\text { Contact } \\
\text { injuries 80\% } \\
\text { Non-contact } \\
20 \%\end{array}$ & $\begin{array}{l}\text { Contusion } 31.4 \% \\
\text { Sprain } 25.7 \% \\
\text { Tendinopathy } 8.6 \% \\
\text { Spasm } 8.6 \% \\
\text { Laceration } 8.6 \% \\
\text { Abrasion } 8.6 \% \\
\text { Other } 8.5 \% \\
\end{array}$ & -- & -- \\
\hline $\begin{array}{l}\text { Emery \& } \\
\text { Meeuwisse } \\
(2006)\end{array}$ & $\begin{array}{ll}\text { Lower } & \text { limb } \\
85.7 \% & \end{array}$ & --- & $\begin{array}{l}\text { Contact } \\
\text { injuries 60\% } \\
\text { Non-contact } \\
40 \% \\
\end{array}$ & --- & $\begin{array}{l}(0 \text { d.) } 14.39 \% \\
\text { (>7 d.) } 31.4 \%\end{array}$ & $\begin{array}{l}\text { Training 26.5\% } \\
\text { Competition } \\
73.5 \%\end{array}$ \\
\hline
\end{tabular}

\section{DISCUSSION}

\section{Factors related to injuries}

Incidence

First, it is worth highlighting that Junge \& Dvorak (2000) concluded that the most adequate strategy to compare the injury rate between sports is to analyse the ratio of injuries-practice time. Out of the 36 epidemiological studies containing specific information on futsal, only 11 reported an injury rate, only 3 performing a comparison between futsal and other sports. Schimikli et al. (2009) analysed the injury rate in 10 different sports and situated futsal in the first position with 55.2 injuries per 10,000 hours of practice. Under the same perspective, Willick et al. (2013) studied this variable in 21 sports and also found the highest injury rate in futsal with 22.4 injuries per 1,000 hours of practice. Finally, Emery \& Meuwisse (2006) compared the injury rate of soccer and futsal and obtained non-significant differences, with 4.45 and 5.59 injuries per 1,000 hours of practice in futsal and soccer, respectively. In brief, it is worth mentioning that, although the injury rate is diverse among the studies consulted (see Table 1), futsal is identified as one of the sports with the highest rate in most of the included studies. This difference in the injury rate could be due to the different definition of injury utilised, apart from the different units used in the ratio.

With this in mind, it is worth comparing the different futsal injury ratios found in the literature. First, it could be observed that ratios between 4.45 and 292.40 injuries/1,000 hours are reported by the literature. In this regard, it should be borne in mind the differences between the study designs, with the prospective studies obtaining higher values. As in the comparison between sports, the definition of injury adopted by the authors could also influence the results. Another factor that could affect the obtained injury ratios is the inclusion of the training as practice time. Normally, the studies not considering training report lower injury ratios.

\section{Body region injured}

Concerning the body region injured, a major number of injuries has been reported to occur in the lower limb, with percentages between 36.9 and $88.2 \%$ as can be seen in Table 2. This result could be expected due to the specific characteristics of futsal (see "Introduction" section). In this sense, the lower limb is under constant stress during futsal practice due to ball control, displacements, and interaction with rivals (Cherati et al., 2016; Emery \& Meeuwisse, 2006; Gayardo et al., 2012; Kurata et al., 2007; Lago-Fuentes et al., 2020; Morato et al., 2013).

\section{Body part injured}

As opposed to the body region injured, there is not a clear consensus on the main body part injured with futsal practice, although the knees and ankles seem to be the main body part injured, followed by the thighs, legs, and feet. The trunk, head, and neck are among the less injured body parts. The existing controversy on the main body part injured with the highest values for the knees and ankles could lay in the constant changes 
of rhythm and direction, ball control and interaction with rivals that take place in futsal. This provokes higher stress in these joints and predisposes athletes to injury (Lago-Fuentes et al., 2020; Quemelo et al., 2012; Varkiani et al., 2013). Specifically, ankle-injury-chances are higher when dribbling and shooting (Aminiaghdam, 2012; Cherati et al., 2016; López-Segovia et al., 2019) and the knee, as is situated in the centre of the lower-limb lever arm, is more exposed with changes of rhythm and direction (Aminiaghdam, 2012). Concerning the head, main injuries have been shown to occur in the mouth and eyes (Collares et al., 2014; Filipe et al., 1997).

\section{Production mechanism}

To understand mechanisms in which injuries occur is crucial to adopt prevention measures for sports. Attending to the results gathered in Table 2 it is difficult to identify injury mechanisms that prevail among others. Specifically, eight studies reported a higher percentage of injuries that occur due to direct contact with rivals (Aminiaghdam, 2012; Dantas \& Silva, 2007; Emery \& Meeuwisse, 2006; Junge \& Dvorak, 2010; LagoFuentes et al., 2020; Morato, Bilzon \& Duarte, 2013; Ribeiro \& Costa, 2006; Willick et al., 2013). Accordingly, Lindenfeld et al. (1994) reported that a major part of injuries occurs due to collisions (30.9\%) and being hit by a rival (16\%). Bearing in mind the ball weight and the smaller pitch size it seems reasonable that futsal presents a high rate of contact injuries (García-Tamez et al., 2011; Luciano \& Lara, 2012; Serrano et al., 2013). On the other hand, some publications give non-contact injuries a higher rate (Gayardo et al., 2012; Ruiz-Pérez et al., 2020). As opposed to injuries occurring due to contact with rivals, non-contact injuries could be associated with deficient strength and conditioning preparation (Aminiaghdam, 2012; Ribeiro \& Costa, 2006), periods of overload, overuse, and/or inappropriate recovery (Aminiaghdam, 2012; Gayardo et al., 2012; Ribeiro \& Costa, 2006). Finally, concerning the relationship between the mechanism that produced the injury and the type of injury that occurred, a higher incidence of bone and joint injuries (fractures, sprains) is associated with contact with rivals, and muscle and ligament injuries (tears, strains, contractures) are mainly caused by non-contact mechanisms (López-Segovia et al., 2019; Ruiz-Pérez et al., 2020; Serrano et al., 2013).

\section{Injury type}

Different conclusions can be extracted after carefully reading the existing literature in this regard. A major part of studies highlights ankle and knee sprains as the main injury happening during futsal practice (Aminiaghdam, 2012; Baroni et al., 2008; Cherati et al., 2016; Dantas \& Silva, 2007; Junge \& Dvorak, 2010; Lago-Fuentes et al., 2020; Lindenfeld et al., 1994; Luciano \& Lara, 2012; Morato et al., 2013; Serrano et al., 2013; Uluöz, 2016). As aforementioned, the constant ball control and disputes with rivals provoke a high demand on these joints and therefore the tendency to injury increases (Panchuk \& Glab, 2015; Quemelo et al., 2012; Varkiani et al., 2013). In a similar way, thigh and leg contusions are pretty common in futsal practice (Aminiaghdam, 2012; Junge \& Dvorak, 2010; Lago-Fuentes et al., 2020; Lindenfeld et al., 1994; Morato et al., 2013). In addition to the overuse of the lower limb (Emery \& Meeuwisse, 2006; Gayardo et al., 2012; Kurata et al., 2007; Morato et al., 2013), other factors such as the material and size of the game field can increase collisions with rivals (García-Tamez et al., 2011; Luciano \& Lara, 2012).

\section{Injury severity}

Regarding this study variable, it is worth highlighting the dissonances between the criteria used by each study to establish the level of severity of the injuries, which could lead to confusion (Medina et al., 2009). For instance, one study only considered injuries that withdraw the athlete from playing at least a week (Emery \& Meeuwisse, 2006). Despite this fact, a major part of studied identified a tendency of reduction in the number of injuries as the severity increases (Aminiaghdam, 2012; García-Tamez et al., 2011; Junge \& Dvorak, 2010; Medina et al., 2009; Ribeiro \& Costa, 2006). Only a few studies reported a higher number of severe injuries 
(Gayardo et al., 2012; Serrano et al., 2013). These dissonances could be explained by the different study designs employed, with the retrospective studies being potentially affected by the memory of subjects (Fuller et al., 2006; Junge \& Dvorak, 2000) or by the mild injuries not being considered as injuries by certain athletes (Gayardo et al., 2012; Ribeiro \& Costa, 2006; Van Mechelen et al., 1992). Finally, attending to the injury mechanism and its severity, non-contact injuries seem to be more severe than contact injuries (Ribeiro \& Costa, 2006).

Injuries occurred in training and injuries occurred in competition

Regarding this variable, it could be interesting to differentiate between the absolute values and the relative values. While the absolute number of injuries is reported to be higher in training than in competitions (Arena \& Carazzato, 2007; Baroni et al., 2008; García-Tamez et al., 2011; Gayardo et al., 2012), due to the higher hours of training compared to competitions (Gayardo et al., 2012), the relative percentage of injuries is higher in competition compared to training (Dantas \& Silva, 2007; Emery \& Meeuwisse, 2006), which could be explained by the higher effort, intensity, and stress applied in competitions (Gayardo et al., 2012).

\section{Position on the field}

Results regarding the differences between the occurred injuries depending on the position on the field are inconclusive, except for the goalkeepers (Baroni et al., 2008; Lindenfeld et al., 1994; Luciano \& Lara, 2012; Serrano et al., 2013). In this concern, as could be expected, goalkeepers present a higher number of upperlimb injuries (Baroni et al., 2008; García-Tamez et al., 2011; Junge \& Dvorak, 2010; Lindenfeld et al., 1994; Luciano \& Lara, 2012), with an article obtaining different results (Serrano et al., 2013). The inconclusive results regarding the influence of the position on the field could be explained through the game structure of futsal, in which players are constantly moving throughout the field and not being limited to one specific area (Baroni et al., 2008; Serrano et al., 2013).

\section{Gender}

A tendency for more ankle injuries in male players and knee in females was observed (Aminiaghdam, 2012; Lindenfeld et al., 1994; Ruiz-Pérez et al., 2020; Serrano et al., 2013; Uluöz, 2016). Among other factors, this fact could be attributed to a) anatomical alignment between hip and knee ( $Q$ angle), b) higher knee joint laxity in female athletes, c) disequilibrium in the ratio hamstring quadriceps strength (Gayardo et al., 2012; Paterson, 2009).

\section{Age}

The age range between 25 and 34 was identified to have the greatest incidence of injuries (Emery \& Meeuwisse, 2010; Lindenfeld et al., 1994; Schmikli et al., 2009; Serrano et al., 2013; Willick et al., 2013). In this regard, Spinks \& McClure (2007) found a positive correlation between age and the incidence of injuries. Only two studies identified higher injury rates under 25 years old (Ahmad-Shushami \& Abdul-Karim, 2020; Varkiani et al., 2013). As a summary and bearing in mind these results, it could be reasonable to think that age is a determinant factor in injury occurrence (Kurata et al., 2007).

\section{Injury prevention}

\section{Equipment}

The first factor acknowledged as crucial to prevent injuries in futsal is the use of appropriate shoes (Berdejodel-Fresno et al., 2013; Patel et al., 2002). Appropriate footwear will diminish reaction forces caused by futsal characteristics and therefore reduce the incidence of injuries (Clará et al., 2010; Faquin et al., 2013). However, a considerable number of players select their shoes attending to the appearance more than the 
functionality (Faquin, 2012). The use of shin guards has also been recognized as relevant to prevent traumatic injuries (Engström \& Renström, 1998; Morato et al., 2013; Patel et al., 2002; Paterson, 2009).

As secondary factors, numerous studies suggest the use of safety goggles (Anderson et al., 2000; Filipe et al., 1997; Kent et al., 2007) and mouth guard (Anderson et al., 2000; Collares et al., 2014; Paterson, 2009), which has been shown to not influence aerobic performance (Anderson et al., 2000). Bandages, orthosis, and braces have been proven useful to prevent ankle sprains (Baroni et al., 2008; Thacker et al., 1999), especially in athletes with a previous history of injuries (Bahr, 2007; Dick et al., 2007; Junge \& Dvorak, 2004). No studies were found analysing the protective equipment of goalkeepers.

Facilities, material, and rules

The bad condition of the field has been identified as a major factor affecting the occurrence of injuries (Bahr, 2007; Gayardo et al., 2012; Patel et al., 2002; Paterson, 2009; Yaghobi \& Goodarzi, 2015). The surface should be even and smooth. Wood or synthetic surfaces are recommended over concrete and tar (Clará et al., 2010). Another material that should be adapted to prevent injuries is the goals. Oppositely to soccer goals, which have to be fixed to the ground, futsal goals should be horizontally movable and present an antioverturn system (Anderson et al., 2000; Patel et al., 2002; Paterson, 2009). Both goals and balls should be adapted to the age of the participants, with smaller sizes for kids (Patel et al., 2002; Paterson, 2009). Referees should be instructed on how to prevent injuries through the compliance of the rules (Bahr, 2007; Engström \& Renström, 1998; Morato et al., 2013; Patel et al., 2002). Also, players should be educated to promote a disciplined game and fair play that could reduce the incidence of injuries (Anderson et al., 2000; Engström \& Renström, 1998).

\section{Physical screening}

Individual preseason assessments have been identified as crucial to identify injury risk in futsal athletes and be able to design prevention and strength and conditioning programs (Arena \& Carazzato, 2007; Bahr, 2007; Engström \& Renström, 1998; Ferreira et al., 2010; Gayardo et al., 2012; Leonardi et al., 2012; Pares et al., 2016; Patel et al., 2002). For instance, ankle injuries have been related to flat foot and supinator and knee injuries to knee valgus (Cain et al., 2007; Ribeiro et al., 2003).

\section{Strength and conditioning and technical-tactical training}

The optimal technical performance and physical condition can be relevant factors in the prevention of injuries (Bahr, 2007; Baroni et al., 2008; Gayardo et al., 2012; Kurata et al., 2007; Patel et al., 2002; Paterson, 2009; Peterson et al., 2000). Appropriate load progression and recovery have to be appropriately adjusted to prevent overloading-related injuries (Bahr, 2007; Kurata et al., 2007; Medina et al., 2009; Paterson, 2009). Proprioception training has been identified as a useful strategy to prevent ankle sprains, especially in athletes with a history of ankle injuries (Bahr et al., 1997; Calatayud et al., 2014; Engström \& Renström, 1998; Junge \& Dvorak, 2004; Morato et al., 2013). Other studies highlighted the necessity to perform strength and conditioning programs in the prevention of knee injuries, particularly anterior cruciate ligament in female athletes (Junge \& Dvorak, 2004; Orr et al., 2011; Patel et al., 2002; Prodromos et al., 2007). Flexibility has also been proposed as a capacity to be trained to prevent injuries, with joint rigidity being directly related to injuries (Araújo et al., 2013). In this regard, a Pilates intervention showed good results in the improvement of flexibility of futsal athletes (Bertolla et al., 2007). Also, an active stretching program of eight weeks improved hip flexion in athletes, which could help to equilibrate the hamstrings-quadriceps strength ratio (Ayala et al., 2010; 2012; Ayala \& de Baranda, 2011).

In addition to strength and conditioning programs, the warm-up has been highlighted as one of the most important factors to prevent injuries (Emery \& Meeuwisse, 2010; Lopes et al., 2013; Reis et al., 2020). These 
authors evaluated the effectiveness of the FIFA 11+ injury prevention program, which included jogging, stretching, balance training, jumps and sprints with changes of direction, and included neuromuscular strength exercises in the warm-up.

\section{Other prevention strategies}

It has been demonstrated that muscle injuries can be detected through the concentrations of certain biomarkers in plasma, such as creatine kinase (CK) and lactate dehydrogenase (LDH), which are risen after a futsal game (de Moura et al., 2012, 2013; Souza et al., 2010). Finally, many studied made emphasis on the importance of preventing mental stress and complying with appropriate sleep, nutrition, and hydration (García et al., 2010; Olmedilla et al., 2018; Patel et al., 2002; Tessitore et al., 2007, 2008).

\section{Limitations of the study}

Although all the procedures, data selection, and analyses have been carefully carried and supervised by experts, there are some limitations that should be listed. First, the comparison and extrapolation of data have to be performed with caution as the characteristics between studies vary. There exist dissonances between the data presented in the expert literature due to different factors: 1) study design and data gathering, 2) definition of injury adopted, 3 ) sample characteristics and sport level. Unanimous criteria should be used to obtain even data regarding the prevention and incidence of injuries in futsal. Further studies are expected to increase the scientific body of knowledge in terms of the incidence and prevention of injuries.

\section{REFERENCES}

Ahmad-Shushami, A. H., \& Abdul-Karim, S. (2020). Incidence of football and futsal injuries among youth in Malaysian games 2018. Malaysian Orthopaedic Journal, 14(1), 28. https://doi.org/10.5704/MOJ.2003.005

Aminiaghdam, S. (2012). Epidemiological analysis of lower extremity injuries during the Iranian universities futsal championship. Medicina dello Sport, 65(4), 527-535.

Anderson, S. J., Griesemer, B. A., Johnson, M. D., Martin, T. J., McLain, L. G., Rowland, T. W., \& Small, E. (2000). Injuries in youth soccer: a subject review. Pediatrics, 105(3), 659-661. https://doi.org/10.1542/peds.105.3.659

Aranda, F. (2006). Written presentation of bibliographic reviews [Presentación por escrito de la revisión bibliográfica]. Secretaría de Ciencia y Técnica, Universidad Adventista del Plata.

Arena, S. S., \& Carazzato, J. G. (2007). Relationship between medical guidance and injuries incidence in Young athlethes from Sao Paulo [A relação entre o acompanhamento médico ea incidência de lesões esportivas em atletas jovens de São Paulo]. Revista Brasileira de Medicina do Esporte, 13(4), 217-221. https://doi.org/10.1590/S1517-86922007000400001

Ayala, F., \& de Baranda, P. S. (2011). Intersession repeatability of finger-plant and finger-ground distance tests to estimate isquisoural flecxibility in adult futsal players of the first division [Reproducibilidad inter-sesión de las pruebas distancia dedos planta y distancia dedos suelo para estimar la flexibilidad isquiosural en jugadores adultos de fútbol sala de primera división]. Revista Andaluza de Medicina del Deporte, 4(2), 47-51.

Ayala, F., Sainz, D. B. P., \& De Ste, C. M. (2010). Effect of active stretch on hip flexion range of motion in female professional futsal players. The Journal of Sports Medicine and Physical Fitness, 50(4), 428-435.

Ayala, F., Sainz, D. B. P., De Ste, C. M. \& Santonja, F. (2012). Absolute reliability of five clinical tests for assessing hamstring flexibility in professional futsal players. Journal of Science and Medicine in Sport, 15(2), 142-147. https://doi.org/10.1016/j.jsams.2011.10.002 
Bahr, R., Lian, O., \& Bahr, I. A. (1997). A twofold reduction in the incidence of acute ankle sprains in volleyball after the introduction of an injury prevention program: a prospective cohort study. Scandinavian Journal of Medicine \& Science in Sports, 7(3), 172-177. https://doi.org/10.1111/j.16000838.1997.tb00135.x

Bahr, R. (2007). Sport injuries: Diagnose, treatment and rehabilitation [Lesiones deportivas: Diagnóstico, tratamiento y rehabilitación]. España: Ed. Médica Panamericana.

Baroni, B., Generosi, R., \& Junior, E. C. P. L. (2008). Incidence and factors related to ankle sprain in athletes of futsal national teams. Physical Therapy in Movement, 21, 79-88.

Baroni, B. M., \& Leal Junior, E. C. P. (2010). Aerobic capacity of male professional futsal players. Journal of Sports Medicine and Physical Fitness, 50(4), 395.

Berdejo-del-Fresno, D., Zagalaz, J. C., Martínez-López, E. J., Sánchez, A. L., \& Diéguez, S. L. (2013). Footprint alterations depending the physical activity performed [Alteraciones de la huella plantar en función de la actividad física realizada]. Revista Internacional de Medicina y Ciencias de la Actividad Física y del Deporte, 13(49), 19-39.

Bertolla, F., Baroni, B. M., Junior, L., Pinto, E. C., \& Oltramari, J. D. (2007). Effects of a training program using the Pilates method in the flexibility of sub-20 indoor soccer athletes. Revista Brasileira de Medicina do Esporte, 13(4), 222-226. https://doi.org/10.1590/S1517-86922007000400002

Cain, L. E., Nicholson, L. L., Adams, R. D., \& Burns, J. (2007). Foot morphology and foot/ankle injury in indoor football. Journal of Science and Medicine in Sport, 10(5), 311-319. https://doi.org/10.1016/j.jsams.2006.07.012

Calatayud, J., Borreani, S., Colado, J. C., Flandez, J., Page, P., \& Andersen, L. L. (2014). Exercise and ankle sprain injuries: a comprehensive review. The Physician and Sports Medicine, 42(1), 88-93. https://doi.org/10.3810/psm.2014.02.2051

Cherati, A. S., Dousti, M., \& Younespour, S. (2016). Association between foot posture index and ankle sprain in indoor football players. Global Journal of Health Science, 8(10), 51426-51426. https://doi.org/10.5539/gihs.v8n10p160

Clará, J. D. R., Soriano, C., Ruth, A., Contreras, C., \& Yuvicza, G. (2010). Ankle and foot musculoskeletal injuries in futsal and related factors in Universidad El Salvador team January-February 2010 [Factores relacionados con lesiones músculo esqueléticas de tobillo y pie en jugadores de fútbol sala de la Selección de la Universidad de El Salvador enero-febrero 2010]. Tesis Doctoral, Universidad de El Salvador, El Salvador.

Collares, K., Correa, M. B., Silva, I. C. M. D., Hallal, P. C., \& Demarco, F. F. (2014). Effect of wearing mouthguards on the physical performance of soccer and futsal players: a randomized cross-over study. Dental Traumatology, 30(1), 55-59. https://doi.org/10.1111/edt.12040

Dantas, J. A., \& Silva, M. R. (2007). Lower limb injuries frequency in profesional futsal [Frequência das lesoes nos membros inferiores no futsal profissional]. Revista da Faculdade de Ciências da Saúde, (4).

de Moura, N. R., Cury-Boaventura, M. F., Santos, V. C., Levada-Pires, A. C., Bortolon, J., Fiamoncini, J., ... \& Hatanaka, E. (2012). Inflammatory response and neutrophil functions in players after a futsal match. The Journal of Strength \& Conditioning Research, 26(9), 2507-2514. https://doi.org/10.1519/JSC.0b013e31823f29b5

de Moura, N. R., Borges, L. S., Santos, V. C., Joel, G. B., Bortolon, J. R., Hirabara, S. M., ... \& Hatanaka, E. (2013). Muscle lesions and inflammation in futsal players according to their tactical positions. The

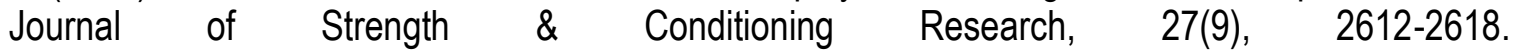
https://doi.org/10.1519/JSC.0b013e31827fd835 
Dick, R., Putukian, M., Agel, J., Evans, T. A., \& Marshall, S. W. (2007). Descriptive epidemiology of collegiate women's soccer injuries: National Collegiate Athletic Association Injury Surveillance System, 1988-1989 through 2002-2003. Journal of Athletic Training, 42(2).

Emery, C. A., \& Meeuwisse, W. H. (2006). Risk factors for injury in indoor compared with outdoor adolescent soccer. The American Journal of Sports Medicine, 34(10), 1636-1642. https://doi.org/10.1177/0363546506288018

Emery, C. A., \& Meeuwisse, W. H. (2010). The effectiveness of a neuromuscular prevention strategy to reduce injuries in youth soccer: a cluster-randomised controlled trial. British Journal of Sports Medicine, 44(8), 555-562. https://doi.org/10.1136/bjsm.2010.074377

Engström, B. K., \& Renström, P. A. (1998). How can injuries be prevented in the World Cup soccer athlete? Clinics in Sports Medicine, 17(4), 755-768. https://doi.org/10.1016/S0278-5919(05)70116-2

Faquin, A. O. (2012). Sport shoes for futsal practice: mechanic, biomechanic and perception assessments [Calçado esportivo destinado à prática de futsal: avaliações mecânicas, biomecânicas e de percepção]. Doctoral Thesis, Universidad de São Paulo, São Paulo.

Faquin, A., Avila, A. V., \& Serrão, J. C. (2013). Plantar pressure distribution in indoor soccer shoes. Footwear Science, 5(sup1), S29-S30. https://doi.org/10.1080/19424280.2013.799537

Ferreira, A. P., Gomes, S. A., Ferreira, C. E. S., Arruda, M. D., \& França, N. M. D. (2010). Evaluate of dominant and nondominant knee extensors and flexors isokinetic performance in futsal athletes. Revista Brasileira de Ciências do Esporte, 32(1), 229-243. https://doi.org/10.1590/S0101$\underline{32892010000400016}$

Federación Internacional Futbol Asociación (FIFA) (2013). Futsal rules [Reglas de Juego del Futsal].

Filipe, J. A.C., Barros, H., \& Castro-Correia, J. (1997). Sports-related ocular injuries: a three-year followup study. Ophthalmology, 104(2), 313-318. https://doi.org/10.1016/S0161-6420(97)30318-2

Filipe, J. A. C., Fernandes, V. L., Barros, H., Falcao-Reis, F., \& Castro-Correia, J. (2003). Soccer-related $\begin{array}{llll}\text { ocular injuries. Archives of } & \text { Ophthalmology, }\end{array}$ https://doi.org/10.1001/archopht.121.5.687

Fuller, C. W., Ekstrand, J., Junge, A., Andersen, T. E., Bahr, R., Dvorak, J., ... \& Meeuwisse, W. H. (2006). Consensus statement on injury definitions and data collection procedures in studies of football (soccer) injuries. Scandinavian Journal of Medicine \& Science in Sports, 16(2), 83-92. https://doi.org/10.1111/j.1600-0838.2006.00528.x

García Jiménez, J. V., Yuste Lucas, J. L., \& García Pellicer, J. J. (2010). Liquid ingestion and dehidration in profesional futsal players depending their field position [Ingesta de líquidos y deshidratación en jugadores profesionales de fútbol sala en función de la posición ocupada en el terreno de juego]. Apunts. Medicina de l'Esport, 45(166), 69-74. https://doi.org/10.1016/j.apunts.2010.02.002

García-Tamez, S. E., Echegoyen-Monroy, S., Ybarra-Barrera, P., \& Rodríguez, M. C. (2011). Epidemiology of injuries in a male college indoor soccer team. Acta Ortopedica Mexicana, 26(4), 219-223.

Gayardo, A., Matana, S. B., \& Silva, M. R. D. (2012). Prevalence of injuries in female athletes of Brazilian futsal: a retrospective study. Revista Brasileira de Medicina do Esporte, 18(3), 186-189. https://doi.org/10.1590/S1517-86922012000300010

Hutton, B., Salanti, G., Caldwell, D. M., Chaimani, A., Schmid, C. H., Cameron, C., loannidis, J. P. A., Straus, S., Thorlund, K., Jansen, J. P., Mulrow, C., Catalá-López, F., Gøtzsche, P. C., Dickersin, K., Boutron, I., Altman, D. G., \& Moher, D. (2015). The PRISMA Extension Statement for reporting of systematic reviews incorporating Network Meta-analyses of health care interventions: Checklist and explanations. Annals of Internal Medicine, 162(11), 777-784. https://doi.org/10.7326/M14-2385 
Junge, A., \& Dvorak, J. (2000). Influence of definition and data collection on the incidence of injuries in football. The American Journal of Sports Medicine, 28(suppl 5), S-40. https://doi.org/10.1177/28.suppl_5.s-40

Junge, A., \& Dvorak, J. (2004). Soccer injuries. Sports Medicine, 34(13), 929-938. https://doi.org/10.2165/00007256-200434130-00004

Junge, A., Dvorak, J., Graf-Baumann, T., \& Peterson, L. (2004). Football injuries during FIFA tournaments and the Olympic Games, 1998-2001 Development and Implementation of an InjuryReporting System. The American Journal of Sports Medicine, 32(1 suppl), 80S-89S. https://doi.org/10.1177/0363546503261245

Junge, A., \& Dvorak, J. (2010). Injury risk of playing football in Futsal World Cups. British Journal of Sports Medicine, 44(15), 1089-1092. https://doi.org/10.1136/bjsm.2010.076752

Kent, J. S., Eidsness, R. B., Colleaux, K. M., \& Romanchuk, K. G. (2007). Indoor soccer-related eye injuries: should eye protection be mandatory? Canadian Journal of Ophthalmology/Journal Canadien d'Ophtalmologie, 42(4), 605-608.

Knowles, S. B., Marshall, S. W., \& Guskiewicz, K. M. (2006). Issues in estimating risks and rates in sports injury research. Journal of Athletic Training, 41(2), 207.

Kurata, D. M., Martins Junior, J., \& Nowotny, J. P. (2007). Injuries incidence in futsal athletes [Incidência de lesões em atletas praticantes de Futsal]. Iniciação Cientifica CESUMAR, 9(1), 45-51.

Ladeira, C. E. (1999). Injury incidence in soccer: a prospective study with adult Canadian male athletes [Incidência de lesões no futebol: um estudo prospectivo com jogadores masculinos adultos amadores canadenses]. Revista Brasileira de Fisioterapia, 4(1), 39-47.

Lago-Fuentes, C., Jiménez-Loaisa, A., Padrón-Cabo, A., Calvo, M. M., García-Pinillos, F., \& Rey, E. (2020). Epidemiology of injuries in elite female futsal players: a prospective cohort study. International Journal of Sports Medicine, 41(12), 885-890. https://doi.org/10.1055/a-1179-6280

Lara Araújo, V., Otoni do Carmo Carvalhais, V., Ribeiro Teles Dos Santos, T., Gomes Pavan Gonçalves, G., Sales Prado, L., \& Teixeira Fonseca, S. (2013). Characterization of hip passive stiffness of volleyball, basketball and futsal young athletes. Physical Therapy in Sport, 14(4), 227-231. https://doi.org/10.1016/j.ptsp.2012.10.002

Leonardi, A. B. D. A., Martinelli, M. O., \& Duarte Junior, A. (2012). Are there differences in strength tests using isokinetic dynamometry between field and indoor professional soccer players? Revista Brasileira de Ortopedia, 47(3), 368-374. https://doi.org/10.1016/S2255-4971(15)30114-2

Lindenfeld, T. N., Schmitt, D. J., Hendy, M. P., Mangine, R. E., \& Noyes, F. R. (1994). Incidence of injury in indoor soccer. The American Journal of Sports Medicine, 22(3), 364-371. https://doi.org/10.1177/036354659402200312

Lopes, M., Simões, D., Costa, R., Oliveira, J., \& Ribeiro, F. (2020). Effects of the FIFA 11+ on injury prevention in amateur futsal players. Scandinavian Journal of Medicine \& Science in Sports, 30(8), 1434-1441. https://doi.org/10.1111/sms.13677

López-Segovia, M., \& Fernández, V. (2019). Preseason Injury Characteristics in Spanish Professional Futsal Players: The LNFS Project. The Journal of Strength and Conditioning Research. https://doi.org/10.1519/JSC.0000000000003419

Luciano, A. D. P., \& Lara, L. C. R. (2012). Epidemiological study of foot and ankle injuries in recreational sports. Acta Ortopedica Brasileira, 20(6), 339-342. https://doi.org/10.1590/S1413$\underline{78522012000600005}$

Medina, J. A., Marqueta, P. M., \& Salillas, L. G. (2009). Incidence of injuries and effects in the training programs in futsal [Incidencia lesional y su repercusión en la planificación del entrenamiento en fútbol sala]. Archivos de Medicina del Deporte: Revista de la Federación Española de Medicina del Deporte y de la Confederación Iberoamericana de Medicina del Deporte, (132), 261-272. 
Morato, M. P., Bilzon, J. L., \& Duarte, E. (2013). Sports injuries in Brazilian blind footballers. International Journal of Sports Medicine, 34(3), 239-243. https://doi.org/10.1055/s-0032-1316358

Olkoski, M. M., Fuke, K., Matheus, S. C., Soares, F. A. A., Portella, R., da Rosa, E. J. F., ... \& Bottaro, M. (2013). Biochemical and physical responses to water and land training in futsal athletes [Respostas bioquímicas e físicas ao treinamento realizado dentro e fora da água em atletas de futsal]. Journal of Physical Education, 19(2), 432-440. https://doi.org/10.1590/S1980$\underline{65742013000200020}$

Olmedilla, A., García-Alarcón, M., \& Ortega, E. (2018). Relationships between sports injuries and stress in female football and indoor football. Journal of Sport and Health Research, 10(3), 339-348.

Orr, B., Brown, C., Hemsing, J., McCormick, T., Pound, S., Otto, D., ... \& Beaupre, L. A. (2011). Female soccer knee injury: Observed knowledge gaps in injury prevention among players/parents/coaches and current evidence (the KNOW study). Scandinavian Journal of Medicine \& Science in Sports, 23(3), 271-280. https://doi.org/10.1111/j.1600-0838.2011.01381.x

Panchuk, T., \& Glab, G. (2015). Indoor soccer injuries: problems and prospects for solving them. Physical Activity, Health and Sport, 1(19), 47-57.

Pares, J., Taboada, C., Temporal, D., \& Carré, C. (2016). Physium in risk reduction of injuries in elite indoor football players: a pilot study. Journal of Sport and Health Research, 8(3), 223-230.

Patel, D. R., Stier, B., \& Luckstead, E. F. (2002). Major international sport profiles. Pediatric Clinics of North America, 49(4), 769-792. https://doi.org/10.1016/S0031-3955(02)00018-4

Paterson, A. (2009). Soccer injuries in children. Pediatric Radiology, 39(12), 1286-1298. https://doi.org/10.1007/s00247-009-1416-1

Peterson, L., Junge, A., Chomiak, J., Graf-Baumann, T., \& Dvorak, J. (2000). Incidence of football injuries and complaints in different age groups and skill-level groups. The American Journal of Sports Medicine, 28(suppl 5), S-51. https://doi.org/10.1177/28.suppl_5.s-51

Prodromos, C. C., Han, Y., Rogowski, J., Joyce, B., \& Shi, K. (2007). A meta-analysis of the incidence of anterior cruciate ligament tears as a function of gender, sport, and a knee injury-reduction regimen. Arthroscopy: The Journal of Arthroscopic \& Related Surgery, 23(12), 1320-1325. https://doi.org/10.1016/j.arthro.2007.07.003

Quemelo, P. R. V., Coelho, A. R., Bachur, J. A., Morraye, M. D. A., Zaia, J. E., \& Gadotti, I. (2012). Prevalence of sport injuries during the 53th Regional Games in Franca (SP), Brazil. Fisioterapia e Pesquisa, 19(3), 256-260. https://doi.org/10.1590/S1809-29502012000300011

Reis, I., Rebelo, A., Krustrup, P., \& Brito, J. (2013). Performance enhancement effects of Federation Internationale de Football Association's "The 11+" Injury Prevention Training Program in Youth Futsal Players. Clinical Journal of Sports Medicine, 23(4), 318-320. https://doi.org/10.1097/JSM.0b013e318285630e

Ribeiro, C. Z. P., Akashi, P. M. H., Sacco, I. D. C. N., \& Pedrinelli, A. (2003). Relationship between postural changes and injuries of the locomotor system in indoor soccer athletes. Revista Brasileira de Medicina do Esporte, 9(2), 98-103. https://doi.org/10.1590/S1517-86922003000200005

Ribeiro, R. N., \& Costa, L. O. P. (2006). Epidemiologic analysis of injuries occurred during the 15th Brazilian Indoor Soccer (Futsal) Sub20 Team Selection Championship. Revista Brasileira de Medicina do Esporte, 12(1), 1-5. https://doi.org/10.1590/S1517-86922006000100001

Ruiz-Pérez, I., López-Valenciano, A., Jiménez-Loaisa, A., Elvira, J. L., Croix, M. D. S., \& Ayala, F. (2019). Injury incidence, characteristics and burden among female sub-elite futsal players: a prospective study with three-year follow-up. PeerJ, 7, e7989. https://doi.org/10.7717/peeri.7989

Schmikli, S. L., Backx, F. J., Kemler, H. J., \& Van Mechelen, W. (2009). National survey on sports injuries in the Netherlands: target populations for sports injury prevention programs. Clinical Journal of Sports Medicine, 19(2), 101-106. https://doi.org/10.1097/JSM.0b013e31819b9ca3 
Serrano, J. M., Shahidian, S., Voser, R. D. C., \& Leite, N. (2013). Incidence and injury risk factors in Portuguese futsal players. Revista Brasileira de Medicina do Esporte, 19(2), 123-129. https://doi.org/10.1590/S1517-86922013000200011

Souza, C. T. D., Medeiros, C. D., Silva, L. A. D., Silveira, T. C., Silveira, P. C., Pinho, C. A. D., ... \& Pinho, R. A. (2010). Serum measurement of muscle and oxidative damage in soccer players after a game. Revista Brasileira de Cineantropometria \& Desempenho Humano, 12(4), 269-274.

Spinks, A. B., \& McClure, R. J. (2007). Quantifying the risk of sports injury: a systematic review of activityspecific rates for children under 16 years of age. British Journal of Sports Medicine, 41(9), 548-557. https://doi.org/10.1136/bjsm.2006.033605

Tessitore, A., Meeusen, R., Cortis, C., \& Capranica, L. (2007). Effects of different recovery interventions on anaerobic performances following preseason soccer training. The Journal of Strength \& Conditioning Research, 21(3), 745-750. https://doi.org/10.1519/00124278-200708000-00015

Tessitore, A., Meeusen, R., Pagano, R., Benvenuti, C., Tiberi, M., \& Capranica, L. (2008). Effectiveness of active versus passive recovery strategies after futsal games. The Journal of Strength \& Conditioning Research, 22(5), 1402-1412. https://doi.org/10.1519/JSC.0b013e31817396ac

Thacker, S. B., Stroup, D. F., Branche, C. M., Gilchrist, J., Goodman, R. A., \& Weitman, E. A. (1999). The prevention of ankle sprains in sports $A$ systematic review of the literature. The American Journal of Sports Medicine, 27(6), 753-760. https://doi.org/10.1177/03635465990270061201

Uluöz, E. (2016). Investigation of sport injury patterns in female futsal players. International Journal of Sports Culture and Science, 4(4), 474-488.

Urrútia, G., \& Bonfill, X. (2010). PRISMA Declaration [Declaración PRISMA: Una propuesta para mejorar la publicación de revisiones sistemáticas y metaanálisis]. Medicina Clínica, 135(11), 507-511. https://doi.org/10.1016/j.medcli.2010.01.015

Van Mechelen, W., Hlobil, H., \& Kemper, H. C. (1992). Incidence, severity, aetiology and prevention of sports injuries. Sports Medicine, 14(2), 82-99. https://doi.org/10.2165/00007256-199214020-00002

Varkiani, M. E., Alizadeh, M. H., \& Pourkazemi, L. (2013). The epidemiology of futsal injuries via Sport Medicine Federation Injury Surveillance System of Iran in 2010. Procedia-Social and Behavioral Sciences, 82, 946-951. https://doi.org/10.1016/j.sbspro.2013.08.001

Willick, S. E., Webborn, N., Emery, C., Blauwet, C. A., Pit-Grosheide, P., Stomphorst, J., ... \& Schwellnus, M. (2013). The epidemiology of injuries at the London 2012 Paralympic Games. British Journal of Sports Medicine, 47(7), 426-432. https://doi.org/10.1136/bjsports-2013-092374

Yaghobi, M. \& Goodarzi, B. (2015). Comparative study of sports injuries in football and futsal team. European Academic Research, 3(4), 6662-6673.

Zagalaz, J. C. (2011). Incidence of the new rules of futsal in Spain (2006) in the show [Análisis de la incidencia en el espectáculo deportivo del nuevo reglamento de Fútbol sala (2006) en España]. Apunts. Educación física y deportes, (106), 84.

Zagalaz, J. C., Rodrigo-Conde Salazar, M., Campoy-Aranda, T. J., \& Linares-Girela, D. (2012). Futsal and education. Learning a team sport in school [Fútbol sala y educación. Aprendizaje de un deporte colectivo para los escolares]. Journal of Sport and Health Research, 4(3), 145-254.

\section{(@)}

This work is licensed under a Attribution-NonCommercial-NoDerivatives 4.0 International (CC BY-NC-ND 4.0). 